\title{
True mountain mahogany community and shrub size responses to browsing
}

\author{
DEBORAH TURLEY, BRUCE A. ROUNDY, AND SCOTT C. WALKER
}

Authors are former Graduate Assistant, Professor Department of Integrative Biology, Brigham Young University, Provo, Utah 84602; and Wildlife Biologist and Project Leader, Great Basin Research Center, Utah Division of Wildlife Resources, Ephraim, Utah 84627.

\begin{abstract}
True mountain mahogany (Cercocarpus montanus Raf.) provides nutritional winter forage for big game species in the mountain brush zone. To determine browsing effects, animal use, percent vegetation cover, and shrub dimensions were measured inside and outside exclosures up to 7 years old on 4 sites on the North Slope of the Unita Mountains, and at an exclosure $>50$ years old in the Wasatch Mountains, Utah. Utilization was measured in an associated twig demography study. Winter big game use increased from 1997 to 1999 at the North Slope. Utilization of annual growth ranged from 21 to over $300 \%$, depending on the site and year and did not necessarily parallel animal use. Greater than $100 \%$ utilization of annual growth resulted when previous years' wood was browsed. There was little difference in vegetation cover, species richness, and diversity inside and outside the exclosures, but mountain mahogany had lower cover and smaller size outside than inside the exclosures at 3 North Slope sites. Mahogany cover was similar, but width and breadth of shrubs were smaller outside than inside the $>\mathbf{5 0}$-year old exclosure in the Wasatch Mountains. Browsed shrubs maintained their size from 1995 to 1999 at the North Slope, despite over $100 \%$ utilization of annual growth at 3 of the sites in at least 1 year. True mountain mahogany is highly tolerant of winter browsing, and can compensate for $>100 \%$ utilization of annual growth by increased growth during wet years. However, continued use of over $100 \%$ of annual growth could reduce cover, shrub size, and forage production during years of lower resource availability. A practical management approach is to monitor cover and size of shrubs inside and outside well-placed exclosures across the winter range over time, and reduce herd numbers as appropriate to allow browsed shrubs to maintain or reach the size of unbrowsed shrubs when their growth has leveled off after a few years of exclusion.
\end{abstract}

Key Words: utilization, grazing, big game, winter range, herbivory, Utah, mountain brush, exclosures, moose, deer, elk, pronghorn, Cercocarpus montanus

True mountain mahogany (Cercocarpus montanus Raf.), is one of the most important browse species in the mountain brush zone (Holechek et al. 2001), which is located between the sagebrush (Artemisia spp L.)-grasslands and juniper (Juniperus spp L.) or

Research was funded by the Utah Division of Wildlife Resources and Brigham Young University Professional Development Funds.

Manuscript accepted 13 Feb. 03.
Resumen

En la zona montañosa de arbustos el "True mountain mahogany" (Cercocarpus montanus Raf.) suministra durante el invierno forraje nutritivo para la fauna silvestre mayor. Para determinar los efectos del ramoneo se midió el uso animal, porcentaje de cobertura y dimensiones de los arbustos dentro y fuera de exclusiones de hasta 7 años de establecidas en 4 sitios de la exposición Norte de las montañas Unita y en una exclusión de mas de 50 años en las montañas Wasatch, en Utah. La utilización se midió en un estudio asociado sobre demografía de ramillas. El uso de esta especie por la fauna silvestre mayor se incremento de 1997 a 1999 en la exposición Norte. La utilización del crecimiento anual varió de 21 a más del $300 \%$, dependiendo del sitio y el año y no necesariamente del uso animal paralelo. La utilización de más del $100 \%$ del crecimiento anual resultó cuando la madera del año previo fue ramoneada. Hubo una pequeña diferencia en la cobertura de la vegetación, riqueza de especies y diversidad dentro y fuera de las exclusiones, pero el "Mountain mahogany" tuvo una cobertura más baja y un menor tamaño fuera que dentro de las exclusiones en los tres sitios de la exposición norte. La cobertura de "Mahogany" fue similar, pero lo ancho y alto de los arbustos fue más pequeña fuera que dentro de la exclusión de más de 50 años de establecida en las montañas Wasatch. Los arbustos ramoneados mantuvieron su tamaño del 1995 a 1999 en la exposición norte, a pesar de que su grado de utilización fue más del $100 \%$ de su crecimiento anual, lo que ocurrió en los tres sitios al menos durante un año. "True mountain mahogany"es altamente tolerante al ramoneo invernal y puede compensar la utilización de más del $100 \%$ del crecimiento anual al incrementar su crecimiento durante los años húmedos. Sin embargo, el uso continuo de más del $100 \%$ del crecimiento anual pudieráa reducir la cobertura y tamaño del arbusto y la producción de forraje durante los años de baja disponibilidad de recursos. Una estrategia práctica de manejo es monitorear la cobertura y tamaño de los arbustos dentro y fuera de exclusiones bien ubicadas a lo largo del pastizal de invierno y a través del tiempo y reducir el tamaño del hato en forma adecuada para permitir a los arbustos ramoneados mantener o alcanzar el tamaño de los arbustos sin ramoneo cuando su crecimiento se ha estabilizado después de unos años de exclusión.

aspen (Populus tremuloides Michx.)-fir (Abies spp Miller) zones. The high nutritional value of its leaves and young shoots (Brotherson 1992, Rominger et al. 1988), make it a valuable forage for deer (Odocoileus hemionus), elk (Cervus elaphus), moose (Alces alces), Rocky Mountain bighorn sheep (Ovis canadensis), pronghorn antelope (Antilocapra americana), mountain goat 
(Oreamnos americanus), and livestock (USDA Forest Service 1931, Kufeld 1973, Wasser 1982, Rominger et al. 1988). True mountain mahogany shrub communities are found throughout the Great Basin and Rocky Mountains between 1070 and 3050 $\mathrm{m}$ (Greenwood and Brotherson 1978). The lower elevational range of this species makes it more available as winter forage than curlleaf mountain mahogany (Cercocarpus ledifolius Nutt. in T. \& G., Davis 1990).

Many shrub species common to the mountain brush zone require moderate browsing to maintain high productivity (Holechek et al. 2001). Lower current year's production of true mountain mahogany within big game exclosures compared to browsed shrubs outside the exclosures in southeastern Wyoming led Waugh (1990) to conclude that some utilization was necessary for optimum production and to avoid stagnation and decadence. Tolerance of browsing depends on the ability of the shrub to replace the biomass removed by herbivory. Biomass replacement depends on the shrub's ability to capture and allocate resources for growth from surviving meristematic tissue (Roundy and Ruyle 1989, Bilbrough and Richards 1993). True mountain mahogany is evidently tolerant of moderate to heavy browsing, recovers within 2 to 3 years after heavy use, and has increased growth when browsed (Young 1956, Shepherd 1971, Davis 1990). True mountain mahogany clipped in winter or spring up to $90 \%$ of previous year's growth exactly compensated for lost tissue by greater growth of long shoots (Wandera et al. 1992). However, Shepherd (1971) found that when greater than $80 \%$ of annual growth was removed by clipping, shrub biomass decreased; and when greater than $100 \%$ annual growth was clipped, mahogany shrubs were dead within 10 years. Since ability of shrubs to compensate for tissue removal can be affected by resource availability (Wandera et al. 1992), and actual herbivory may differ from clipping (Trlica and Rittenhouse 1993), effects of herbivory should be measured under field conditions to provide management guidelines.

Heavy winter utilization by big game of true mountain mahogany communities on the North Slope of the Uinta Mountains led to the establishment of big game exclosures in 1992 and 1993 by the USDA Forest Service. Our purpose was to compare animal use, utilization, and plant community and shrub characteristics associated with browsed and unbrowsed true mountain mahogany communities to provide future utilization and management guidelines.

\section{Methods}

\section{Study Sites}

Study sites included 1 exclosure in the Wasatch Mountains and 4 exclosures on the North Slope of the Unita Mountains
(Table 1). The Wasatch Mountain exclosure is in Gardner Creek Canyon, approximately $5 \mathrm{~km}$ north of Nephi, Utah, east of I-15 in the foothills, and located inside the Mount Nebo Wilderness Area. The exclosure was established in the 1930s with barbed wire and then reinforced in 1945 with net wire. The plant community is codominated by true mountain mahogany and squawapple (Peraphyllum ramosissimum Nutt. in T. \& G.). Average annual precipitation is 400 to $560 \mathrm{~mm}$, and mean annual temperature is 5 to $7^{\circ} \mathrm{C}$ (NOAA 1995-1999).

The Uinta North Slope region is located in Summit County, Utah near the border between Wyoming and Utah. Four exclosures were built from 1992 to 1993 in mountain mahogany dominant communities known for being heavily grazed by elk (Table 1). Serviceberry (Amelanchier alnifolia (Nutt.) Nutt.) is associated with mahogany at the Gregory Basin and Telephone Hollow sites, while sagebrush (Artemisia L.) is associated or dominant in nearby communities at the Poison and Widdop Mountain sites.

\section{Animal Use}

Although pellet count surveys have been used for population surveys and to create an index of habitat use for wildlife (Neff 1968, Collins 1981, Loft and Kie 1981), they have been found to overestimate populations (Babcock 1977). Loft and Kie (1981) found pellet count studies to overand underestimate habitat use. Despite the

Table 1. Site characteristics of true mountain mahogany communities in Utah where browsing was excluded.

\begin{tabular}{|c|c|c|c|c|c|c|c|}
\hline Site & Geology & Soil & Aspect & Location & Slope & Elevation & $\begin{array}{l}\text { Years of } \\
\text { Exclusion } \\
\text { by } 1999\end{array}$ \\
\hline Gardner Canyon & limestone, shale & $\begin{array}{l}\text { Bezzant gravelly loam series } \\
\text { of loamy-skeletal, mixed, } \\
\text { frigid typic calciborolls }\end{array}$ & $\begin{array}{l}\text { North, } \\
\text { South }\end{array}$ & $\begin{array}{l}\text { N } 39^{\circ} 45^{\prime} \\
\text { W } 111^{\circ} 48.8^{\prime}\end{array}$ & $\begin{array}{l}(\%) \\
44\end{array}$ & $\begin{array}{c}(\mathrm{m}) \\
1820\end{array}$ & $>50$ \\
\hline Gregory Basin & $\begin{array}{l}\text { Wasatch } \\
\text { formation, } \\
\text { landslide deposits }\end{array}$ & $\begin{array}{l}65 \% \text { of Tinsley family of } \\
\text { sandy skeletal, mixed frigid, } \\
\text { typic ustorthents; } 25 \% \\
\text { rock outcrop }\end{array}$ & North & $\begin{array}{l}\text { N } 40^{\circ} 58^{\prime} \\
\text { W } 110^{\circ} 6\end{array}$ & $10-30$ & 2520 & 7 \\
\hline Poison Mountain & limy shale, sandstone & $\begin{array}{l}\text { Gravelly, heavy silt loams, } \\
\text { over gravelly, clay loam } \\
\text { subsoil }\end{array}$ & East & $\begin{array}{l}\text { N } 40^{\circ} 58^{\prime} \\
\text { W } 110^{\circ} 14.5\end{array}$ & $20-40$ & 2730 & 7 \\
\hline Telephone Hollow & $\begin{array}{l}\text { Mississippian } \\
\text { limestone }\end{array}$ & $\begin{array}{l}40 \% \text { of Marden family deep; } \\
25 \% \text { of Windhem family } \\
\text { moderately deep, loamy- } \\
\text { skeletal, carbonatic, typic } \\
\text { calciborolls; } 20 \% \text { rocky } \\
\text { outcrop }\end{array}$ & South & $\begin{array}{l}\text { N } 40^{\circ} 57.7^{\prime} \\
\text { W } 110^{\circ} 4.8^{\prime}\end{array}$ & $20-40$ & 2675 & 7 \\
\hline Widdop Mountain & \multicolumn{2}{|c|}{ same as Telephone Hollow } & South & $\begin{array}{l}\text { N } 40^{\circ} 57.1^{\prime} \\
\text { W } 110^{\circ} 4.5^{\prime}\end{array}$ & $40-60$ & 2645 & 6 \\
\hline
\end{tabular}


variability, pellet counts are useful in creating an indirect index of ungulate abundance or habitat use (Franzmann and Schwartz 1997, Goodrich et al. 1999). Pellet groups were surveyed at the North Slope of the Uintas in June 1997, 1998, and 1999 to provide an index of ungulate use during winter (1 September to mid-June).

Four pellet group lines were surveyed at each site, starting at the exclosure corners and walking away from the exclosures. Pellet group lines terminated at the end of the mountain mahogany community or at a maximum of $100 \mathrm{~m}$, whichever came first. The width of the line was $1.3 \mathrm{~m}$ and all groups found within that area were counted and cleared so that groups would not be counted the following spring.

Animal use was calculated using the number of pellet groups and defecation rates for large ungulates. Winter defecation rates of 13 pellet groups per individual per day were used for both mule deer (Neff 1968), and elk (USDA Forest Service 1974). Babcock's (1977) rate of 17.9 pellet groups per individual per day for the Shiras herd on the North Slope of the Uinta Mountains was used for moose. Because of the difficulty in distinguishing between deer and antelope pellet groups, these groups were combined as 1 estimate.

\section{Utilization}

Branches were diagrammed on browsed shrubs at each site in fall after summer growth, and again in spring to determine winter utilization as described by Turley et. al (2003). Three branches were diagrammed on each of 3 to 10 shrubs, depending on the site. Utilization for a winter period was calculated as the percentage of total length removed of total growth during the previous summer for all measured branches for a given shrub. Utilization was greater than $100 \%$ when previous years' growth was browsed.

\section{Vegetation Communities}

Vegetation was measured in May 1999 for the Gardner Canyon site, and July 1999 for all North Slope, Uinta Mountain sites. Three transect lines were placed inside and outside the exclosure at each site. Transects ranged from 23 to $30 \mathrm{~m}$ among sites according to the length of the exclosure. Cover classes were recorded every $1.5 \mathrm{~m}$ in a $0.25 \mathrm{~m}^{2}$ quadrat according to Davis et al. (1995). Cover classes were: 1 $=0.01-1 \%, 2=1.1-5 \%, 3=5.1-25 \%, 4=$ $25.1-50 \%, 5=50.1-75 \%, 6=75.1-95 \%, 7$ $=95.1-100 \%$. The cover classes were converted to the midpoint of the estimate and averaged for each transect line.
Species richness and MacArthur's (1972) diversity index were calculated by vegetation category, site, and treatment using average percent cover data. Ruzicka (1958) similarity indices were calculated from average percent cover of the individual species and the general cover categories of the community. Analysis of variance (ANOVA) was done within sites and between treatments on percent cover by species and life form category.

\section{Shrub Dimensions}

At Gardner Canyon, cover transects were also used to describe a $1.3-\mathrm{m}$ wide by $30-\mathrm{m}$ long belt transect. Canopies of all true mountain mahogany shrubs within these transects were measured in 1998 for maximum height, maximum width, and breadth (width perpendicular to maximum width). At the North Slope, 5 shrubs in each cover transect were similarly measured in 1995, 1996, 1997, and 1999. Shrubs measured for size at each site included those for which branches were diagrammed to calculate utilization.

Mixed-model ANOVA approach of the Statistical Analysis System (Littell et al 1996) was used to compare shrub dimensions. Fixed effects included browsed or unbrowsed treatment; random effects included plants within treatment at the Gardner Canyon site. Fixed effects included treatment and site; random effects included plant within treatment and within site for the North Slope sites. Repeated measures ANOVA was also done for North Slope sites with year as a continuous variable. Backwards elimination was done in which nonsignificant effects were taken out of the model to achieve greater sensitivity of the test by estimating the error terms more accurately. P-values < 0.25 may show trends. To be conservative with field estimates, nonsignificant effects were taken out only if the p-value was > 0.25 . Random effects were eliminated first, and then fixed effects when necessary. A square root transformation was performed on all data prior to analysis.

\section{Results and Discussion}

\section{Animal Use}

Total animal use ranged from 8 to 156 animal days/ha (Fig. 1). Although pellet group surveys indicated substantial animal use of the North Slope sites, dominant use by a single species varied with the site. Elk and moose were the primary winter browsers on the North Slope with lesser use by antelope/deer and cattle on some sites. Zornes (1994) found moose and elk pellets common throughout true mountain mahogany communities on the North Slope area. Gregory Basin is part of a cattle allotment, and both Poison Mountain and Telephone Hollow are adjacent to cattle allotments. Cattle graze these areas in the summer and use was most prominent in 1999. Antelope and deer also use these areas in summer and winter and may be browsing mahogany year round. Beale and Smith (1970) found pronghorn to lightly utilize curlleaf mountain mahogany and dwarf mountain mahogany (Cercocarpus intricatus Wats.) as winter forage.

Rocky Mountain bighorn sheep have been introduced back to the North Slope of the Uinta Mountains. No pellet groups were found, but difficulty in identifying pellet groups by species may account for this. During this study, no bighorn sheep were seen at the sites, but were seen in the surrounding areas.

Widdop Mountain received greatest animal use while Poison Mountain had least use. Use increased on all sites from the winter of $1996 / 1997$ to that of $1998 / 1999$. Pellet groups were only surveyed at Gardner Canyon after the winter of $1998 / 1999$, but no pellet groups were found. Snowfall in 1999 was light, and elk and deer may not have been forced onto the lower elevation mahogany communities at Gardner Canyon that year.

\section{Utilization}

Utilization did not mirror animal use values and was highly variable among sites and years at the North Slope (Fig. 1). Over $100 \%$ of annual growth was browsed during the winters of $1996 / 1997$ or $1997 / 1998$ for 2 of the 4 sites at the North Slope and for the Gardner Canyon site. Animals browsed second and third year growth, as well as annual growth on these sites. Twig growth at the North Slope was greatest in 1997 and 1998, and at Gardner Canyon in 1998 (Turley et al. 2003). After peaking in the winter of $1997 / 1998$, utilization dropped to less than $65 \%$ for all sites in the winter of 1998/1999. Greater growth in 1997 and 1998 may have resulted in less utilization in the winter of $1998 / 1999$, even though animal use was high (Fig. 1).

\section{Cover and Diversity Responses}

Overall, vegetation cover inside and outside the exclosures was similar (Fig. 2). All sites but Gardner Canyon and Gregory Basin had greater cover of true mountain mahogany inside than outside the exclosure. The Gardner Canyon site had few vegetation differences after over 50 years. 

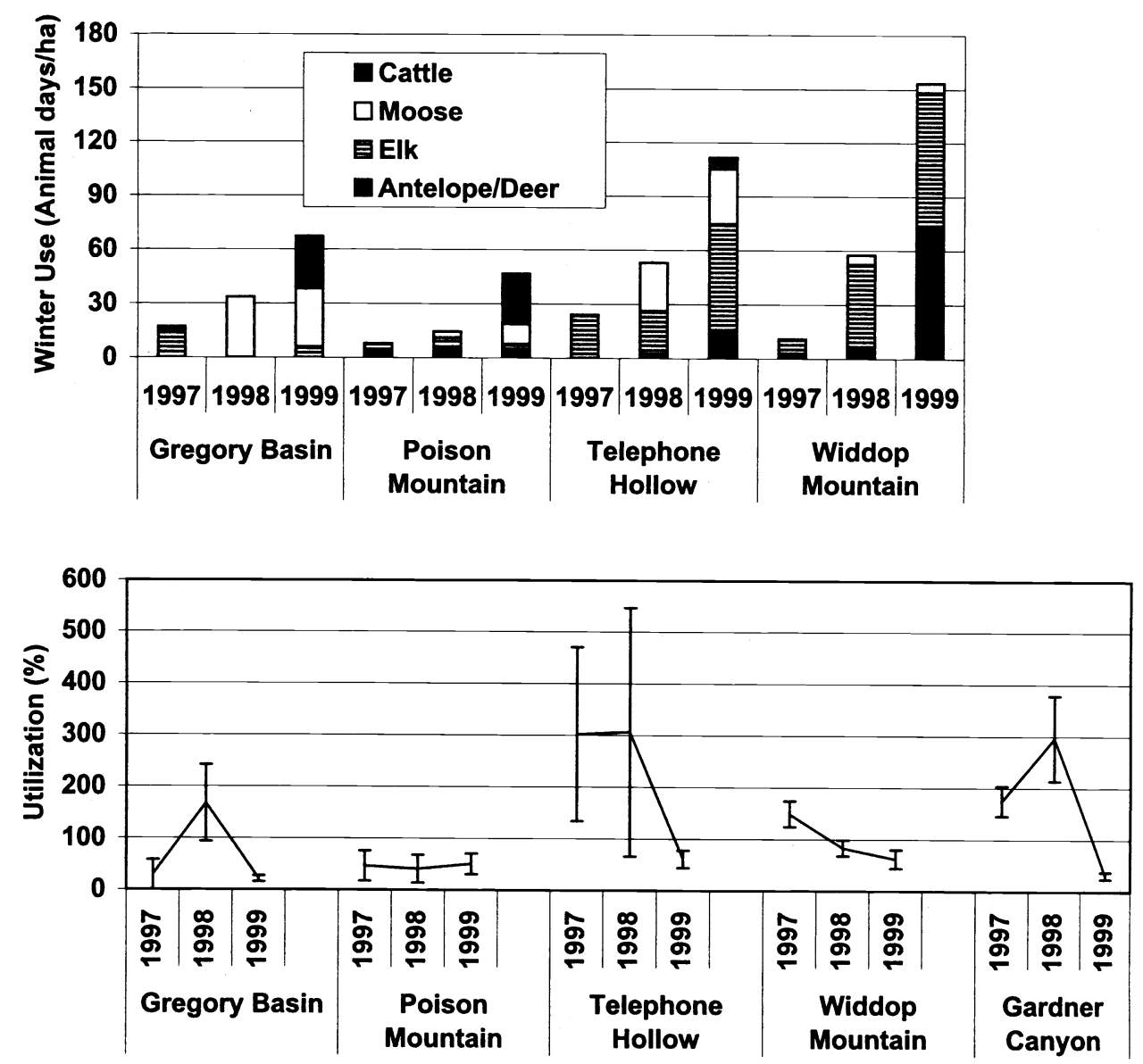

Fig. 1. Winter animal use (above) on 4 true mountain mahogany stands on the North Slope of the Uinta Mountains, Utah, and utilization (below) of mahogany as a percentage of annual growth on those stands and at Gardner Canyon, Wasatch Mountains, Utah.

Squaw apple cover was greater inside $(17.8 \%)$ than outside $(5.7 \%)$, while cover of snakeweed (Guterrizia sarothrae (Pursh) Britt. and Rusby) was greater outside $(6.3 \%)$ than inside $(0.5 \%)$ at Gardner Canyon. Slender buckwheat (Eriogonum microthecum Nutt.) had greater cover inside $(2.1 \%)$ than outside $(0.8 \%)$ at Gregory Basin. At Telephone Hollow, black sagebrush (Artemisia nova Willd.) had $0.4 \%$ cover inside and $4 \%$ cover outside the exclosure. Shrub species richness and diversity were generally similar inside and outside the exclosures (Table 2). Additional shrub species included serviceberry, big sagebrush, green rabbitbrush (Chrysothamnus viscidiflorus (Hook) Nutt.), Oregon grape (Mahonia repens (Lindl.) G. Don), snowberry (Symphoricarpos oreophilus Gray), and horsebrush (Tetradymia canescens DC).

The dominant graminoids at Gregory Basin, and Telephone Hollow were bluebunch wheatgrass (Elymus spicatus (Pursh) Gould) and sedges (Carex spp. L.), with bluebunch wheatgrass also dominant at Widdop Mountain. Greater cheatgrass
(Bromus tectorum L.) inside than outside the Gardner Canyon exclosure may be related to spring grazing. The increase of shrub cover and decrease of forb cover inside the Telephone Hollow exclosure may indicate initial community changes. Nixon (1961) also found forbs to decrease with increased tree cover at an exclosure site in the mountain brush zone.

Penstemon spp. Mitch. had greater cover outside $(<0.1 \%)$ than inside $(0.2 \%)$ the exclosure at Poison Mountain, whereas dandelion (Taraxacum officinale Weber ex Wiggins) was greater inside $(0.6 \%)$ than outside $(0.1 \%)$. Most sites had a wide variety of forbs and forb species richness was similar inside and outside the exclosures (Table 2). An exception was Gardner

Table 2. Species richness and MacArthur diversity index (MacArthur 1972) by site and browsing treatment calculated with percent cover data from inside and outside 5 exclosures in true mountain mahogany communities in Utah in July 1999.

\begin{tabular}{|c|c|c|c|c|c|c|}
\hline \multirow[b]{2}{*}{ Site and treatment } & \multicolumn{3}{|c|}{ Species Richness } & \multicolumn{3}{|c|}{ Diversity Index } \\
\hline & Graminoids & Forbs & Shrubs & Graminoids & Forbs & Shrubs \\
\hline Gardner Canyon Unbrowsed & 3 & 6 & 4 & 1.72 & 1.03 & 2.06 \\
\hline Gardner Canyon Browsed & 4 & 12 & 4 & 1.54 & 1.16 & 2.40 \\
\hline Gregory Basin Unbrowsed & 7 & 22 & 9 & 2.7 & 9.04 & 1.90 \\
\hline Gregory Basin Browsed & 8 & 23 & 8 & 2.65 & 7.37 & 1.55 \\
\hline Poison Mountain Unbrowsed & 12 & 29 & 7 & 6.48 & 6.50 & 2.40 \\
\hline Poison Mountain Browsed & 11 & 27 & 7 & 5.35 & 6.00 & 3.68 \\
\hline Telephone Hollow Unbrowsed & 7 & 13 & 8 & 2.52 & 2.83 & 1.24 \\
\hline Telephone Hollow Browsed & 8 & 19 & 7 & 2.36 & 6.20 & 2.30 \\
\hline Widdop Mountain Unbrowsed & 6 & 19 & 9 & 2.26 & 5.83 & 1.42 \\
\hline Widdop Mountain Browsed & 7 & 15 & 8 & 2.21 & 5.23 & 1.57 \\
\hline
\end{tabular}



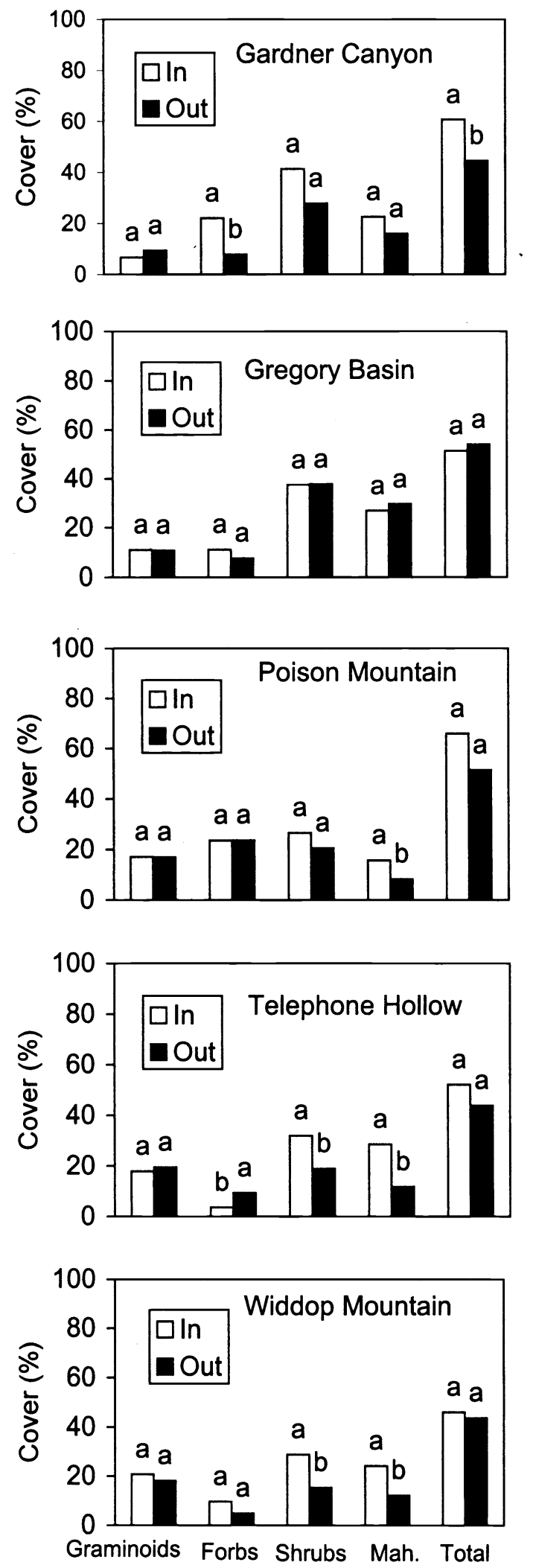

Fig. 2. Vegetation cover inside and outside big game exclosures on 1 true mountain mahogany stand at Garner Canyon, Wasatch Mountains, and at 4 stands on the North Slope of the Uinta Mountains, Utah. Different letters between inside and outside for a vegetation class and site indicate a significant difference $(P<0.05)$. Mah. $=$ true mountain mahogany.
Canyon where lower species richness inside than outside was due to dominance inside by alyssum (Alyssum alyssoides (L.) L.) $(22.1 \%$ cover inside vs. $7.8 \%$ outside).

Ruzicka percent similarity indices showed greatest similarity within individual sites and between browsed and unbrowsed communities at the North Slope (Table 3). One exception in the individual species index was that the Telephone Hollow unbrowsed community had a greater similarity to both browsed and unbrowsed communities at Gregory Basin than to the Telephone Hollow browsed community. Cover category indices had higher similarity and less distinction between browsed and unbrowsed communities and sites than indices calculated using individual species. Similarity calculated by the Ruzicka index depends more on dominant than less dominant species (Hajdu 1981). The Gardner Canyon site had a similarity index of $40.7 \%$ for individual species and $69.8 \%$ for general cover between browsing treatments. Browsed and unbrowsed communities at Gardner Canyon and Telephone Hollow were the least similar for all sites.

\section{Shrub Dimensions}

Unbrowsed mahogany shrubs at Gardner Canyon in 1998 had significantly greater crown width and breadth than browsed shrubs (Fig. 3). Although browsing was associated with decreased shrub size, it has not resulted in reduced height compared to unbrowsed shrubs. Browsed shrubs at this site evidently have reached their maximum height or they are out of reach of ungulates.

Shrub dimensions at the North Slope varied with site, browsing treatment, year, and the interaction of site and treatment (Fig. 4). Unbrowsed shrubs at Poison Mountain and Telephone Hollow had significantly greater height, crown width, and crown breadth than browsed shrubs for all years measured, while unbrowsed shrubs at Widdop Mountain were not larger than browsed shrubs until 1999.

Shrubs inside the exclosures at Telephone Hollow increased in size after initial exclusion, but leveled off in growth in subsequent years (Fig. 4). Browsed shrubs at Poison Mountain were smaller than browsed shrubs at all other sites at the North Slope, even though utilization at this site was less than at the other sites. Ferguson (1968) found that bitterbrush shrubs were able to reach mature height in 7 years within an exclosure, and within 11 to 12 years outside the exclosure while heavily browsed shrubs remained smaller. 
Table 3. Ruzicka's (1958) percent similarity index calculated on individual species (lower left portion) and general cover categories (upper right portion) of true mountain mahogany communities on 4 browsing exclosures at the North Slope of the Uinta Mountains, Utah, using cover percentages.

\begin{tabular}{|c|c|c|c|c|c|c|c|c|}
\hline & \multicolumn{2}{|c|}{ Gregory Basin } & \multicolumn{2}{|c|}{ Poison Mountain } & \multicolumn{2}{|c|}{ Telephone Hollow } & \multicolumn{2}{|c|}{ Widdop Mountain } \\
\hline & Unbrowsed & Browsed & Unbrowsed & Browsed & $\overline{\text { Unbrowsed }}$ & Browsed & Unbrowsed & Browsed \\
\hline \multicolumn{9}{|c|}{ Gregory Basin } \\
\hline Unbrowsed & & 85.43 & 76.38 & 81.20 & 86.80 & 80.37 & 83.88 & 84.06 \\
\hline Browsed & 71.37 & & 84.56 & 75.37 & 89.81 & 74.57 & 72.86 & 72.11 \\
\hline \multicolumn{9}{|c|}{ Poison Mountain } \\
\hline Unbrowsed & 25.02 & 28.24 & & 68.18 & 82.92 & 67.45 & 66.02 & 65.48 \\
\hline Browsed & 21.12 & 22.81 & 53.74 & & 74.40 & 71.72 & 74.74 & 73.20 \\
\hline \multicolumn{9}{|c|}{ Telephone Hollow } \\
\hline Unbrowsed & 56.99 & 63.12 & 25.28 & 23.23 & & 76.50 & 73.75 & 74.15 \\
\hline Browsed & 36.20 & 34.96 & 23.61 & 26.86 & 49.11 & & 86.72 & 92.46 \\
\hline \multicolumn{9}{|c|}{ Widdop Mountain } \\
\hline Unbrowsed & 43.06 & 43.31 & 24.38 & 17.63 & 55.30 & 40.45 & & 34 \\
\hline Browsed & 31.43 & 31.97 & 21.96 & 21.98 & 43.64 & 53.91 & 57.42 & \\
\hline
\end{tabular}

Shrubs excluded from browsing appear to have recovered to near potential size in just 2 years at Telephone Hollow. Excluded shrubs were still increasing in size after 7 years at Poison Mountain. Evidently browsed shrubs at Gregory Basin are at their potential size because they are the same size as shrubs excluded from browsing for 7 years. At Widdop Mountain, unbrowsed shrubs did not exceed size of browsed shrubs until after the wetter years of 1997 and 1998. These results indicate the interaction between resource availability and response to herbivory or the lack thereof and suggest caution in applying results from 1 time and space to other sites and years (Noy-Meir 1993).

\section{Management Implications}

Effects of herbivory should be measured at a range of scales relevant to the scale of management decisions (Brown and Allen 1989, Trlica and Rittenhouse 1993). Differences in browsed true mountain mahogany communities and those unbrowsed for over 50 years in the Wasatch Mountains, and for 6 to 7 years on the North Slope of the Uinta Mountains were not substantial and would be of limited concern to managers, except for the lower cover of true mountain mahogany itself on 3 of 4 sites at the North Slope. Lower cover of browsed than unbrowsed mahogany at Poison Mountain, Telephone Hollow, and Widdop Mountain was associated with smaller browsed than unbrowsed shrubs at these sites. Lower cover and size of browsed shrubs was not necessarily associated with higher utilization of annual growth at these sites during the study period. For example, utilization at Poison Mountain was 46, 41, and 50\%, while that at Telephone Hollow was 302, 306 , and $61 \%$ for the winters of
$1996 / 1997,1997 / 1998$, and 1998/1999 (Fig. 1). Both utilization and growth varied yearly during the study period and there was no clear relationship between amount of utilization and size among browsed shrubs at different sites. However, that unbrowsed shrubs at 4 sites were larger than browsed shrubs indicates failure of regrowth to exactly compensate for browsed tissue sometime in the past.

Proportional growth of browsed twigs was greater than that of unbrowsed twigs at these sites (Turley et al. 2003). This growth compensation replaced twig length lost to browsing at all sites, regardless of utilization, and allowed browsed shrubs to maintain, but not increase in size. Higher annual precipitation in 1998 at Gardner Canyon and in 1997 and 1998 at the North Slope produced greater twig growth for these years (Turley et al. 2003). This increased twig growth would have resulted in greater biomass production of mountain mahogany throughout the area and may have resulted in decreased utilization at the North Slope in the winter of 1998/1999 even though animal use was still high (Fig. 1). This suggests that years of greater resource availability may allow over- compensation of growth and maintenance of shrub size even when utilization exceeds $100 \%$ on some years. For managers, the risk is that dry or normal years with reduced or average growth coupled with high utilization may result in under compensation and decreased shrub cover, size, forage production, and range carrying capacity.

Holechek et al. (2001) have made a strong case for moderate stocking of livestock such that only $40 \%$ of annual growth of grasses is utilized. They cite numerous long term studies to show that such moderate utilization is the best way to maintain and improve rangelands where grasses are a dominant component. Less attention has been given to guidelines for managing big

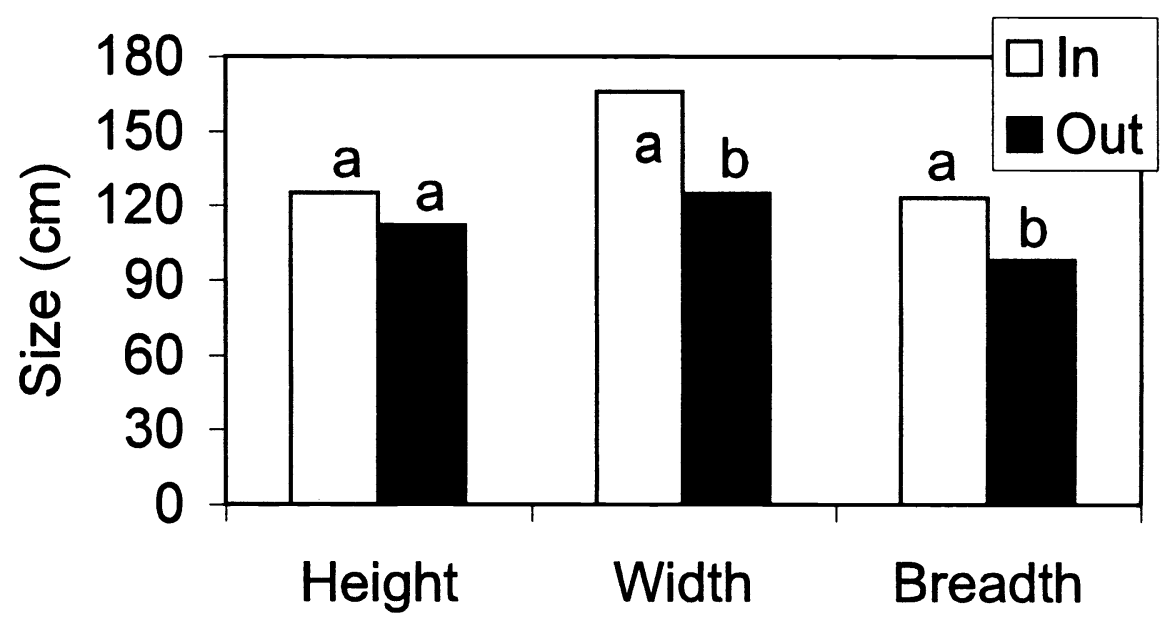

Fig. 3. Dimensions of true mountain mahogany shrubs measured in 1998 inside and outside a $>50$ year-old exclosure at Gardner Canyon, Wasatch Mountains, Utah. Different letters for a dimension indicate a significant difference $(P<0.05)$. 

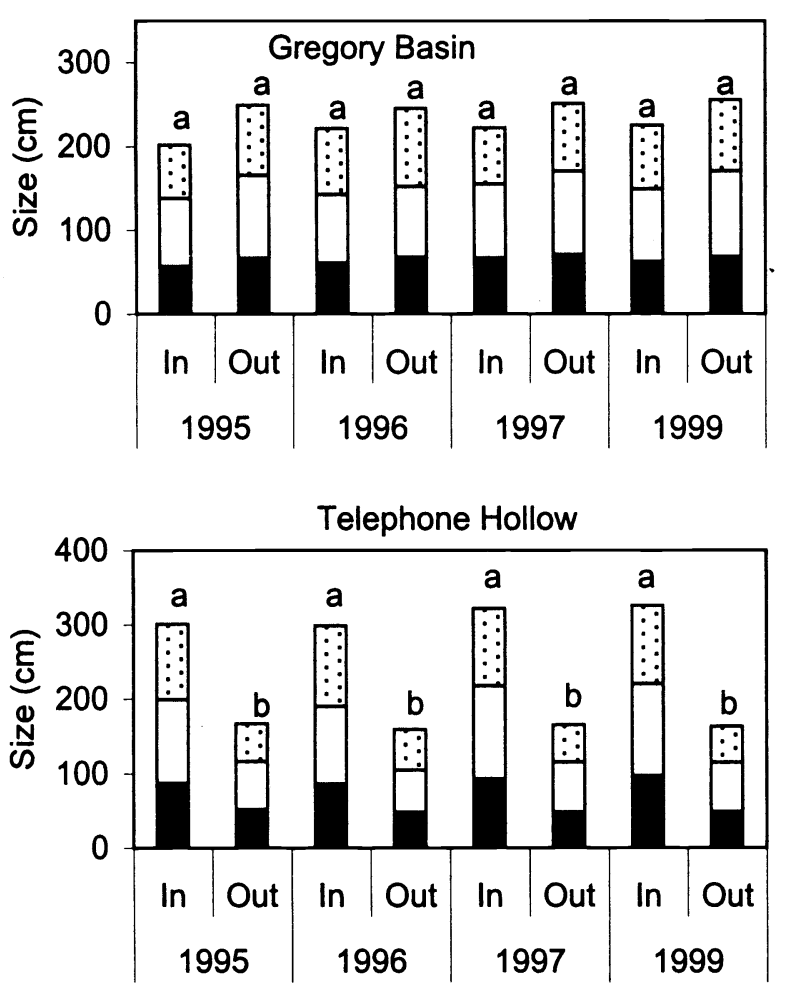
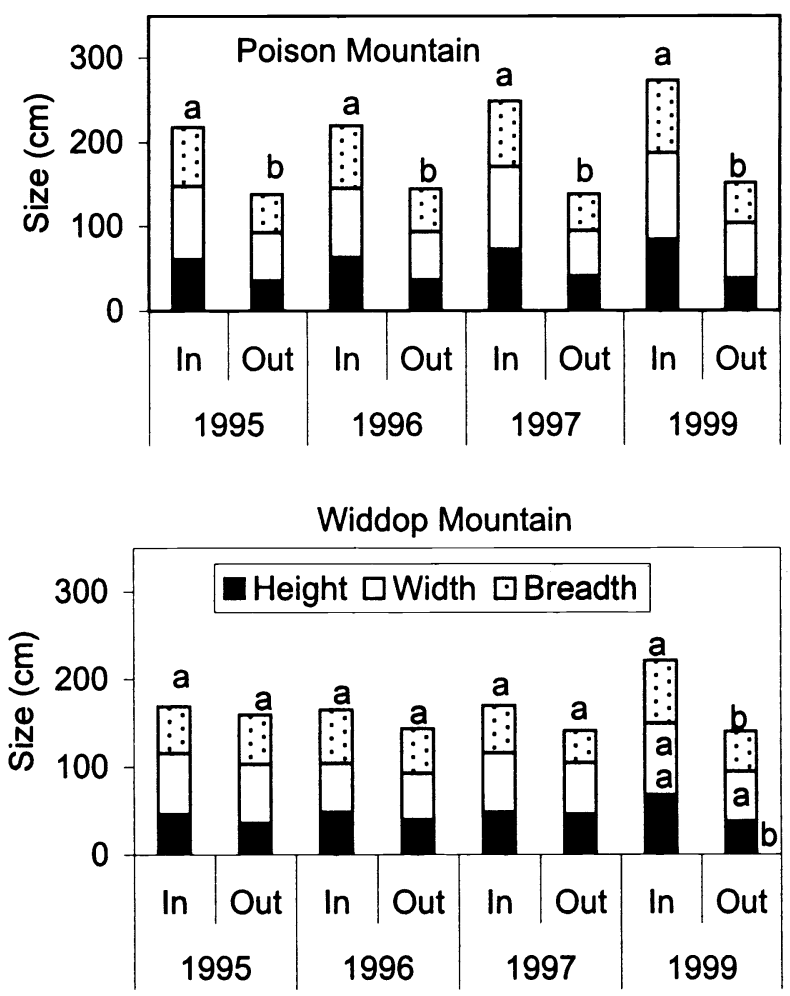

Fig. 4. Dimensions of true mountain mahogany shrubs inside and outside browsing exclosures on 4 sites on the North Slope of the Uinta Mountains, Utah. All dimensions were statistically compared separately. Different letters within a year and site indicate a significant difference $(P<0.05)$ between inside and outside for all dimensions measured, unless labeled for each dimension.

game on ranges where browsing-tolerant shrubs are the dominant and key forage species. The greater size of true mountain mahogany in this study after just 2 years of exclusion, suggests that on some sites, utilization has been so high that even with years of high resource availability, compensatory growth is not enough to allow shrubs to reach their potential size for the site, thus limiting their potential forage production. Although browsed shrubs did not diminish in size during the study period, their size could have been reduced without the greater precipitation and growth that occurred in 1997 and 1998.

It is difficult to manage big game stocking for specific utilization on certain sites. High animal use in combination with dry or normal years may diminish shrub size by increasing utilization of reduced growth. Subsequent dry or normal years may not allow over-compensation to replace over-utilized growth. Conservative range management would require that grazing-tolerant shrubs such as true mountain mahogany be utilized at less than $100 \%$ of annual growth on years of maximum utilization. Monitoring of shrub size and cover is much easier than twig demography measurements to accurately deter- mine utilization, but is also less sensitive to yearly growth and utilization effects. Perhaps the most practical approach, is to monitor cover and size of shrubs inside and outside well-placed exclosures across the winter range over time, and reduce herd numbers as appropriate to allow browsed shrubs to reach the size of unbrowsed shrubs when their growth has leveled off after a few years of exclusion.

\section{Literature Cited}

Babcock, W.H. 1977. Continuing investigations of the Uinta North Slope moose herd. Publication Number 77-19, Federal Aid Project W-65-RD-22. Utah Dept. of Natural Resources, Div. of Wildl. Resources. Salt Lake City, Utah.

Beale, D. M. and A. D. Smith. 1970. Forage use, water consumption, and productivity of pronghorn antelope in western Utah. J. Wildlife Manage. 34:570-582.

Bilbrough C.J. and J.H. Richards. 1993. Growth of sagebrush and bitterbrush following simulated winter browsing: mechanisms and tolerance. Ecol. 74:481-492.

Brotherson, J.D. 1992. Mineral-nutrient concentrations in the mountain mahogany species Cercocarpus montanus and
Cercocarpus intricatus and in their associated soils. J. Plant Nut.15:49-67.

Brown, B.J. and T.F.H. Allen. 1989. The importance of scale in evaluating herbivory impacts. OIKOS 54: 189-194.

Collins W.B. 1981. Habitat preferences of mule deer as rated by pellet-group distributions. J. Wildlife Manage. 45:969-972.

Davis, J.N. 1990. General ecology, wildlife use, and management of the mountain mahoganies in the Intermountain West. p.1-14 In: K.L. Johnson (ed.) Proc.Fifth Utah Shrub Ecology Workshop: The genus Cercocarpus. Utah State University. Logan, Utah.

Davis, J. N., M. Farmer, J.L. Vernon, D.C. Kelley, and A.J. Whitworth. 1995. Utah big game range trend studies. Publication Number 98-1. Federal Aid Project W-135-R16. Utah Department of Natural Resources, Division of Wildlife Resources, Salt Lake City, Utah.

Ferguson, R.B. 1968. Survival and growth of young bitterbrush browsed by deer. J. Wildl. Manage. 32:769-773.

Franzmann, A.W. and C.C. Schwartz. 1997. Ecology and management of the North American moose. Smithsonian Institution Press, Washington, D.C.

Goodrich S., E. D. McArthur, A. Huber, and J.E. Ott. 1999. Ungulate browsing of two populations of rubber rabbitbrush. p.196-199. In: E.D. McArthur, W.K. Ostler 
and C. L. Wambolt (compilers) Proc Shrubland ecotones. USDA Forest Service Rocky Mountain Research Station. RMRS-P11, Ogden, Utah.

Greenwood L.R. and J.D. Brotherson. 1978. Ecological relationships between pinyonjuniper and true mountain mahogany stands in the Uintah Basin, Utah. J. Range Manage. 31:164-167.

Hajdu, J. 1981. Graphical comparison of resemblance measures in phytosociology. Vegetatio 48:47-59.

Holechek, J. L., R. D. Pieper, and C. H. Herbel. 2001. Range management principles and practices. Fourth edition. Prentice Hall, Upper Saddle River, N.J.

Kufeld R.C. 1973. Foods eaten by the Rocky Mountain Elk. J. Range Manage. 26:106-113.

Littell, R.C., G.A. Milliken, W.W. Stroup, and R.D. Wolfinger. 1996. SAS system for mixed models. SAS Institute Inc. Cary, N.C.

Loft E.R. and J. G. Kie. 1981. Comparison of pellet-group and radio triangulation methods for assessing deer habitat use. J. Wildl. Manage. 52:524-527.

MacArthur, R.H. 1972. Geographical ecology: patterns in distribution of species. Harper and Row, Publishers, New York, NY.

Neff, D.J. 1968. The pellet-group count technique for big game trend, census, and distribution: a review. J. Wildlife Manage. 32:597-614.

Nixon, E.S. 1961. An ecological study of an exclosure in the mountain brush vegetation of the Wasatch Mountains, Utah. MS Thesis. Brigham Young Univ., Provo, Utah.
NOAA. 1995-1999. Climatological data Annual report for Utah. National Climatic Data Center, Ashville, N.C.

Noy-Meir, I. 1993. Compensating growth of grazed plants and its relevance to the use of rangelands. Ecol. App. 3: 32-34.

Rominger, E.M., A.R. Dale, and J.A. Bailey. 1988. Shrubs in the summer diet of rocky mountain bighorn sheep. J. Wildl. Manage. $52: 47-50$

Roundy, B.A. and G.B. Ruyle. 1989. Effects of herbivory on twig dynamics of a Sonoran desert shrub Simmondsia chinensis (Link) Schn. J. App. Ecol. 26:701-710.

Ruzicka, M. 1958. Anwendung mathematischstatisticher methoden in der geobotanik (synthetische bearbeitung von aufnahmen). Biologia, Bratislava 13:647-661.

Shepherd, H.L. 1971. Effects of clipping on key browse species in southwestern Colorado. Game Research Section, Colorado Div. of Game, Fish and Parks Game Range Investigations, Fed. Aid Proj. W-10-R. Tech. Publ. Number 28. State of Colorado, Denver Colo.

Turley, D., B. A. Roundy, and S. C. Walker. 2003. Twig growth and reproductive responses of true mountain mahogany to browsing. J. Range Manage. 56:591-599.

Trlica, M.J. and L.R. Rittenhouse. 1993. Grazing and plant performance. Ecol. App. 3:21-23.

USDA Forest Service. 1931. Range plant handbook. U. S. Gov. Print. Off., Washington, D.C.
USDA Forest Service. 1974. Interagency guidelines for big game range investigations in Idaho. Idaho Fish and Game Department, Bureau of Land Management, USDA Forest Service, Boise, Ida.

Wandera, J. L., J. H. Richards, and R. J. Mueller. 1992. The relationships between relative growth rate, meristematic potential, and compensatory growth of semiarid-land shrubs. Oecologia 90:391-398.

Wasser, C.H. 1982. Ecology and culture of selected species useful in revegetation disturbed lands in the West. FWS/OBS-82/56. Fish and Wildl. Serv., U.S. Dep. Interior. Washington, D.C.

Waugh, W.J. 1990. Stagnation and decadence of Cercocarpus montanus in a southeastern Wyoming big game exclosure. p.89-96. In: K.L. Johnson (ed.), Proc. Fifth Utah Shrub Ecology Workshop: The genus Cercocarpus. Utah State University. Logan, Utah.

Young, S. 1956. Survey and evaluation of big game exclosures in Utah. Dept. of Inform. Bull. Number 24. Federal Aid Project Number W-65-R-3. Utah State Dept. of Fish and Game. Salt Lake City, Utah.

Zornes, M. 1994. Condition classification of true mountain mahogany (Cercocarpus montanus) stands on the north slope of the Uinta Mountains, Wasatch National Forest, Mountain View Ranger District, Mountain View, Wyo. 